\title{
GENERÁCIÓS HATÁS A MUNKAHELYI KONFLIKTUSOKBAN
}

A munkahelyi konfliktusok az élet állandó tényezői, azonban a konfliktusok megítélése, kezelése és azok megélése egyénenként változó lehet. Számos kutatás foglalkozik a klasszikus meghatározás szerinti generációk (boomer, X, Y és Z) különböző munkahelyi aspektusaival. Jelen tanulmány központi témájának a generációk közötti konfliktusok elemzését választották a szerzők. Kutatásuk során arra keresték a választ, hogy munkahelyi környezetben a különböző korosztályú emberek között kialakuló nézeteltérések valóban generációs problémákból fakadnak-e, tényegesen létezik-e az a szakadék a fiatal és idősebb munkavállaló között, amely a munkahelyi konfliktusok kialakításában szerepet játszik. Kutatásuk alapján a különböző generációba tartozó munkavállalók eltérő módon viselkednek konfliktushelyzetben. A tartósan fennálló ellentétek káros hatásai azonosíthatók egyéni és szervezeti dimenzióban egyaránt. A fiatal munkavállalók konfliktushelyzetben inkább versengők, a konfliktusokat destruktív jelenségként ítélik meg, míg a boomereket inkább az együttműködő magatartás jellemzi. A különböző generációk tagjai egyetértenek abban, hogy a munkahelyi konfliktusok jellemzően értékrendi és kommunikációs tényezőkre vezethetők vissza. Következtetésük alapján a munkahelyi konfliktusok negatív hatásai csökkenthetők a szervezetek értékalapú munkaerő-kiválasztási és -beillesztési kompetenciáinak fejlesztésével.

Kulcsszavak: generációmenedzsment, munkahelyi konfliktus, értékrend

A társadalom tagjai különbözö értékekkel, képességekkel és egyéniséggel rendelkeznek, így az emberek különböző módon viselkednek az adott helyzetekben és döntéseiket eltérő szempontok alapján hozzák meg. Jelenleg négy generáció aktív a munkaerőpiacon (boomer, $\mathrm{X}$, Y, Z), amely különleges kihívás elé állítja a szervezeteket (Meretei, 2017; Becton et al., 2014). Az üzleti lapok és a témakörhöz kapcsolódó kutatások (Shragay - Tziner, 2011; Szabó - Kiss, 2013; Messarra, 2016) alapján a munkahelyi vezetők számára a generációs tényezők jelentik az egyik legnagyobb kihívást. Az egyes generációk között attitüdkülönbségek figyelhetök meg, amelyek a családi és társas kapcsolataikon túlmenöen a munkahelyeken is éreztetik hatásukat, amely Lancaster és Stillman (2002) szerint motivációs prioritásukban is tetten érthető.

Tanulmányunk célja a munkahelyi konfliktusok generációs hatásának feltárása, továbbá a konfliktusok munkahelyi közösségekre gyakorolt hatásának elemzése.

\section{Irodalmi áttekintés}

\section{A generáció fogalmi meghatározása}

A generáció fogalmának lehatárolása tudományterületenként jelentős különbségeket mutat. A témakörben Meretei (2017) összefoglalta a nemzetközi szakirodalmak alapján a legmeghatározóbb rendező elveket és csoportosította a generáció modern fogalmának értelmezési aspektusait (1. táblázat).
1. táblázat A generáció fogalmi lehatárolása

\begin{tabular}{|l|l|}
\hline $\begin{array}{l}\text { Generációcsoportosító } \\
\text { ismérv }\end{array}$ & Szerzők \\
\hline $\begin{array}{l}\text { A generációk elsődleges } \\
\text { jellemzője } \\
\text { a kollektív öntudat }\end{array}$ & $\begin{array}{l}\text { Mannheim, 1952; } \\
\text { Kupperschmidt, 2000; } \\
\text { Arnett, 2000; } \\
\text { Deal et al., 2010; } \\
\text { Ward, 1974 } \\
\text { Schuman-Scott, 1989 }\end{array}$ \\
\hline $\begin{array}{l}\text { Életkor, kohorsz és } \\
\text { a korszakok jelentik } \\
\text { a generációk lehatárolását }\end{array}$ & $\begin{array}{l}\text { Lyons-Kuron, 2014; } \\
\text { Tolbize, 2008; } \\
\text { Twenge, 2000; } \\
\text { Inglehart, 1977 }\end{array}$ \\
\hline $\begin{array}{l}\text { Szervezet szocializációs } \\
\text { folyamatok }\end{array}$ & $\begin{array}{l}\text { Kertzer, 1983; } \\
\text { Khera-Malik, 2014; } \\
\text { Joshi, 2011 }\end{array}$ \\
\hline
\end{tabular}

Forrás: Meretei (2017) alapján saját szerkesztés

Hagyományos értelemben a generációt a szülők és utódaik születése közötti átlagos időintervallumaként definiálhatjuk, amely megközelítőleg 20-25 éves ciklust jelent, azonban a gyermekvállalási idő kitolódása miatt napjainkban a biológiai értelmezés minden eddiginél hosszabb időszakot jelentene, ezért ez a megközelítés mára már irrelevánssá vált. A fogalom megközelíthető szociológiai szempontból is, miszerint a generáció azonos korban 
született személyek csoportja, akik jellemzőit ugyanaz az időszak és annak sajátos eseményei határozták meg. Howe et al. (2000) szerint a generáció olyan személyek csoportja, akik azon a történelmi időn és téren osztoznak, mely kollektív személyiséget biztosít nekik. Ha a generáció meghatározásánál a fogalom biológia értelmezését vesszük alapul, akkor elmondható, hogy a generációkba a megközelítőleg azonos életkorú egyedeket soroljuk (Hale et al., 1997). Álláspontunk szerint Mccrindle és Wolfinger (2010) foglalta össze a legkomplexebb és legátfogóbb módon a generáció definícióját, ezért ez a megközelítés képezi kutatómunkánk alapját: ,, a generációt olyan személyek csoportjaként határozzuk meg, akik ugyanabban a korszakban születtek, ugyanazon idöszak formálta öket, és ugyanazon társadalmi markerek voltak hatással rájukmás szóval a generáció egy azonos életkor és életszakasz, létfeltételek és technológia, események és tapasztalatok által összekapcsolt csoportja”. A tény, hogy egy adott generációra ugyanazon társadalmi, gazdasági, politikai vagy technológiai tényezők voltak hatással nem eredményezi azt, hogy a generáció minden tagja homogén személyiséggel, azonos tulajdonságokkal vagy attitüddel rendelkezik. Ugyanakkor nyilvánvaló a környezeti tényezők hatása az egyének és a generációk szocializálódására, ami szélsőséges esetben generációs szakadék kialakulásához is vezethet, melynek áthidalása kihívást jelent a munkáltatók számára.

\section{Generációk jellemzése}

\section{Boomer generáció (1946-1965)}

A baby boomerek a II. világháború után bekövetkezett gazdasági növekedésbe születtek (Weil, 2008), akik hüségükről ismertek és a szó pozitív értelmében munkamániások voltak (Crampton - Hodge, 2007). A boomerek a veteránok gyermekei, szemléletük azonban jelentősen eltér szüleikétöl. A változásokhoz való viszonyuk pozitívabb, optimistábbak és derülátóbbak elödeiknél, kevésbé fontos számukra a tekintélyelvüség és egyre inkább előtérbe helyezik az egyenjogúságot. Szabadabb felfogásukat azonban tükrözi, hogy rövidebb távra terveznek mind a párkapcsolatok, mind a munkahelyek terén (Zubány, 2008). A boomerek hajlandóak áldozatot vállalni karrierjükért (Kupperschmidt, 2000), továbbá hajlandóak a változások elfogadására is (Crampton - Hodge, 2007). A munkában értékelik a sikereket, a csapatmunkát és a kihívásokat, fenntartják a kedvező kapcsolatokat feletteseikkel, elismerik kollégáik jelentőségét (Karp et al., 2001). Munkakultúrájukat a teljesítmény határozza meg, és nagyra értékelik a munkahely iránti hüséget és elkötelezettséget (Lancaster - Stillman, 2002; Shragay - Tziner, 2011).

Tari (2010) a boomerek munkaerő-piaci aktivitásával kapcsolatban úgy fogalmazott, hogy egyfelöl a lassan nyugdíjba menő korosztály, másfelől a munkaerőpiacon még nagyon is jelen lévő ötvenesek, akik egyáltalán nem akarnak öregemberként élni. Magyarországi viszonylatban Besenyei (2016) szerint a rendszerváltás is nagy hatást gyakorolt a Baby Boom generáció életére, ők a nagy vesztesei, akik az állami gondoskodás megszüntével elvesztették lá- buk alól a talajt. A tervgazdálkodást felváltotta a piacgazdaság, amely az előző rendszerhez képest semmit nem garantált, így megjelent a munkanélküliség és a megélhetés is egyre nehezebbé vált. Tari (2010) Besenyeihez hasonlóan kiemeli a szocializmust, amely véleménye szerint meghatározta az idősebb boomerek életfelfogását, akik ,,merev hierarchiához és kemény munkához szoktak, de állandó feltételek között." Ezzel szemben a generáció fiatalabb tagjai már megpróbáltak alkalmazkodni az új feltételekhez, és az állami munkahelyeken kívül kipróbálták magukat a privát üzleti szférában is. Egyre fontosabbá vált számukra az önmenedzselés, mivel az állami gondoskodás megszünésével, már sem munka, sem státusz, sem elismerés nem járt alanyi jogon, megszüntek a „nyugdíjas állások”, ami folyamatos teljesítménykényszert eredményezett.

\section{X generáció (1966-1979)}

Az X generáció egy kihívásokkal teli társadalmigazdasági valóságba születtek (Johnson - Lopes, 2008). A korosztály életét a pénzügyi, családi bizonytalanság, valamint a hirtelen változások és tradíciók hiánya jellemezte (Smola - Sutton, 2002). Ezek a tényezők vezettek ahhoz, hogy az individualizmus meghatározza életüket (Jurkiewicz - Brown, 1998). Az X generáció tagjai olyan családokban nőttek fel, ahol mindkét szülö munkát vállalt (Karp et al., 2001), vagy csak az egyik szülővel éltek, mert ebben az időszakban a válások száma is növekedett (Kupperschmidt, 2000), így az önállóság meghatározó szerepet játszott már gyermekkorukban. Tanulva szüleik túlzott maximalizmusából, már nem a munka az elsődleges az életükben, hanem a munka és a magánélet közötti egyensúly megteremtése (Patterson, 2005; Zubány, 2008) és a stabil családi háttér (O’Bannon, 2001).

Az X generáció alapvetően különbözik az elöző generációktól, természetes számára a változás, a sokszínűség és a több lábon állás. A korosztályt jellemzi a bizonytalanság és kiábrándultság, mivel a gazdasági fordulatok miatt és szüleik élete alapján nem ismeretlen számukra az elbocsátás, a létbizonytalanság fogalma sem (Kupperschmidt, 2000; Lukovszki, 2015).

Az X korosztály lényegesen rugalmasabb, jobban alkalmazkodik a változásokhoz, viszont kevésbé jellemző rájuk az elköteleződés és gyakrabban váltanak munkahelyet (Zubány, 2008). Képzettségükkel kapcsolatban elmondható, hogy magasan kvalifikáltak, nyelveket beszélnek, két vagy akár több diplomával és számítógépes ismeretekkel is rendelkeznek (Besenyei, 2016). Ez a korosztály érzékelhette a munkahelyek bizonytalanságát, így tisztában vannak azzal, hogy az adott pozíció megszerzésénél egy másik jelentkező komoly riválissá válhat, ezért felismerték, hogy az állásinterjúkon kizárólag hiteles, meggyőző kommunikációval lehetnek sikeresek. Megszokták, hogy naprakész információkra van szükségük és hajlandóak érdekkapcsolatokat is kiépíteni (Tari, 2010). Ösztönző számukra, ha egyszerre több feladattal bízzák meg őket és szabad kezet kapnak a feladatok megvalósításában, mindemellett fontos az állandó visszacsatolás munkájukról (Zubány, 2008). 


\section{Y generáció (1980-1995)}

A globalizáció, a média és a rohamosan fejlődő technológia korszakában születtek. Gyermekként a családi életben a központi szerepet töltötték be, minden körülöttük forgott, így bőséges figyelmet kaptak, az elvárások velük szemben magasak, és a szülök nagyfokú önbizalmat keltettek bennük. Jól dolgoznak csoportban, preferálják a csapatmunkát az egyéni erőfeszítések helyett, emellett az összetett feladatok megoldásában is erősnek bizonyulnak. Törekednek kapcsolatot teremteni a vezetöikkel, amely konfliktus tényezőként is megjelenhet, mert az X generációs vezetők inkább a függetlenséget és az egyéni munkát preferálják. A munkahelyeken a mentorálást leginkább igénylő generáció, fontos számukra az egyéni figyelem (Neil, 2010).

Az Y nemzedék szocializálódására nagy hatást gyakorolt a technológiai forradalom, a számítógépek és az internet térnyerése. Az első digitális nemzedékként gyakran emlegetik őket „Internet generációként” is, mivel a számítógép és az internet életük alapvetö részévé vált (Besenyei, 2016; Zubány, 2008). Besenyei (2016) szerint ez a korosztály az első generáció, amely fordítottan szocializálódott. Tudásukat már nemcsak az elődeiktől, hanem egymástól és a világhálóról szerzik meg, valamint a legújabb digitális technológiák kezelésére már ők tanítják meg szüleiket és nagyszüleiket.

Munkahelyválasztás során a pénz és a karrier központi szerepet kap náluk. Munkahelyükhöz kevésbé kötődnek, állásukra egy olyan tényezőként tekintenek, amit bármikor meg lehet változtatni, és ha valamivel nem elégedettek, ezt különösebb érzelmi kötődés nélkül meg is teszik (Tari, 2010). Pontosan meghatározott célokat, követelményeket és konkrét határidőket várnak el feletteseiktől. Kreatív feladatokra és rugalmas munkavégzésre vágynak. Fontos számukra a munka és a magánélet egyensúlya. Ez a nemzedék már nem áldoz fel mindent a munka oltárán, elengedhetetlen számukra a szabadidő. Magas szintủ elvárásaik miatt megtartásuk kihívást jelent a munkáltatók számára (Zubány, 2008). Elörejelzések szerint ez a generáció fogja betölteni öt éven belül a globális munkaerőpiac 50 százalékát, ezért a munkáltatók számára elengedhetetlen az Y generáció megismerése.

\section{A Z generáció (1995-2010)}

A Z nemzedék a demográfiai tényezők szempontjából jelentős eltérést mutat a korábbi generációkhoz képest, ugyanis abban az időszakban születtek, amikor az egy anyára jutó gyermekek száma kettő alá csökkent. A születések számának jelentős visszaesése azt eredményezte, hogy a családok minden eddiginél kisebbek lettek. Ez az egyik legkisebb létszámú generáció, akit idősebb és nem ritkán egyedülálló édesanyák neveltek, ők vesznek részt legtovább az oktatásban, és jellemző rájuk az élethosszig tartó tanulás (Ferincz - Szabó, 2012; Keszi-Szeremlei Piricz, 2015). Minden tényező közül számukra legfontosabb a munka-magánélet egyensúly megteremtésének lehetösége (Pregnolato et al.,, 2017; Krajcsák, 2018). A Z generáció az első globális generáció, akik a high-tech technológiákat készségszinten sajátították el és alkalmazzák a mindennapokban. Környezetüket a bizonytalanság jellemzi, ez meghatározza világnézetüket a munkával és a tanulmányaikkal kapcsolatban is. Generációs sajátosságként jelenik meg, hogy különböző elvárásaik vannak a potenciális munkahelyekkel kapcsolatban. Karriervágyuk és szakmai ambíciójuk is jelentős, azonban technikai és idegen nyelvi tudásuk messze a legmagasabb szinten áll a többi generációhoz képest. A Z generáció e tulajdonságai miatt kiváló munkaerő. A munkáltatóknak nagy figyelmet kell fordítaniuk a munkahelyi feltételek kialakítására a generáció elköteleződésének érdekében (Elmore, 2014; Bencsik - Machova, 2016). Egy olyan generációról van szó, amelyik a hatalomkultúrával nem tud azonosulni, a hagyományos motivációs eszközök nem alkalmasak elkötelezettségük növelésére (Smola - Sutton, 2002).

Kockázatvállaló korosztály, kimondottan élvezik a csapatmunkát és a bizonytalan karrierút sem riasztja viszsza őket. Az Y generációhoz hasonlóan a $Z$ nemzedék is nagyra értékeli az egyén szabadságát, az önmegvalósítást, és alapvetően elutasítja a formalitásokat. Számukra nagyon fontos a magas fizetés, hozzászoktak a felgyorsult világhoz, így az anyagiak terén sem akarnak több évtizedet várni álmaik megvalósítására. Tisztában vannak vele, mennyit kell keresniük ahhoz, hogy anyagilag függetlenné váljanak. Ugyanakkor a pénz nem minden, fontos számukra hogy kikkel és milyen körülmények között kell együtt dolgozniuk. Vezetői ambíciókkal rendelkeznek, beosztottként is felmerül bennük az igény arra, hogy visszajelezhessenek feletteseiknek, és elvárják munkájuk folyamatos elismerését, értékelését. Általánosságban elmondható róluk, hogy nem szeretik a kötöttséget, szeretnek rugalmas munkaidőben otthonról dolgozni, ahol saját maguk oszthatják be az idejüket (Molnár, 2016).

Soós (2008) részletezi a Z generáció munkaerő-piaci hátrányait is, miszerint a legfiatalabb generációra túlzott magabiztosság, laza munkafegyelem és - a kevés tapasztalat ellenére - túlságosan magas fizetési elvárás jellemző. A Z generáció a motiválhatóság és a munkahellyel szemben támasztott elvárásai alapján jelentős eltérést mutat az idősebb generációkhoz képest. Egy teljesen más világban szocializálódtak, ahol az emberek közötti kapcsolatok helyét a virtuális világ kezdi átvenni, és alapvető fontosságú az információk gyors áramlása, ami egy teljesen új életfelfogást eredményezett. A $Z$ generáció tagjai egészen más képességekkel, készségekkel és prioritásokkal rendelkeznek, mint elődeik. Érdemes azonban figyelmet fordítani rájuk, mivel tíz év múlva minden ötödik munkavállaló közülük kerül majd ki. Várhatóan ez a generáció a mielőbbi tapasztalatszerzés érdekében fiatalon áll majd munkába. Erre a munkáltatóknak is fel kell készülniük, mivel a fiatal munkavállalókkal való együttmüködés, valamint megszerzésük és megtartásuk elöreláthatólag nem lesz egyszerü feladat (Molnár, 2016; Berke - Köműves, 2016).

\section{Generációk és konfliktusok}

A demográfiai változások a több generációt foglalkoztató munkahelyeken sokszínüséghez vezettek. A diverzifikáció bonyolultságot eredményez, mivel minden generációnak saját munkahelyi elvárásai vannak, ezért perspektíváik is eltérőek, ami a munkahelyi konfliktusokat teremti meg (Smola - Sutton, 2002). 
A konfliktusok részét képezik a mindennapi életünknek. A szakirodalom is széles körben tárgyalja e szó jelentését, szótári értelmezésben a konfliktus két dolog összeütközését jelenti, ha azonban nem elégszünk meg ezzel a meghatározással, azt mondhatjuk, hogy a konfliktus egyet nem értés, ellentét, vita vagy feszültség emberek vagy azok csoportjai között (Nádházy, 2006). A konfliktusokról szóló akár elméleti, akár empirikus irodalom túlnyomó része a konfliktust negatív jelenségnek tartja, anomáliaként tekint rá (Szabó Kiss, 2013). A klasszikus vezetéselméleti irányzat képviselői is a konfliktusra zavaró, káros jelenségként tekintettek, amely rombolja a közösséget és ártalmas a szervezetre nézve. A vezetésfelfogás átalakulásával azonban megváltozott ez a vélemény. A Human Relations irányzat időszakában a csoportok együttmüködésének természetes velejárójaként tekintettek a konfliktusokra, amit el kell fogadni és kezelésüket meg kell tanulni. Szerintük minden nézeteltérés vezetési hiányosságokra vezethető vissza, amelyből azonban a szervezetnek haszna is származhat, mivel felhívja a figyelmet a problémás területekre. A munkahelyi stressz növekedésével erősödhetnek a szerepkonfliktusok (Makra et al., 2012), ami szintén befolyásolja a pszichés jóllétet, illetve a munkával és az élettel való elégedettséget (Molnár - Orosz, 2017).

Napjainkban a konfliktusokról alkotott vélemények azonban pozitív irányba váltottak. A legújabb irányzatok képviselői szerint az ellentétek nem csak szükségszerüek, de hasznosak is lehetnek. Támogatják felszínre kerülésüket, mivel azok olyan változásokat idézhetnek elö, amelyek elősegítik a vállalatok környezethez való alkalmazkodását, növelik a szervezeti tagok elégedettségét, továbbá biztosítják a szervezet rugalmasságát, problémamegoldó és válaszképességét (Bakacsi, 2015; Berke - Kömüves, 2016). Svelta (2014) szerint ,, a konfliktus nem rendelkezik elöjellel”, tehát a konfliktus lehet egyaránt pozitív és negatív jelenség is. Felhívja azonban a figyelmet, hogy a nem megfelelöen kezelt konfliktus komoly feszültségforrás lehet, amit mindenképp kezelni kell abban az esetben, ha rontja a munkahelyi légkört vagy a munka eredményességének rovására megy.

Egyes szerzők (Elida-Tomita, 2010; Tjosvold et al., 2003) a konstruktív és a destruktív konfliktus fogalmát különítették el. A szerzők destruktív konfliktusként értelmezik azokat a helyzeteket, amelyek további hibákat generálnak, ahol a problémák nem kerülnek megoldásra a megfelelö időintervallumon belül, és rontják a csoport teljesítményét, amely frusztrációt szül. Mindezek az emberek védekező magatartásához vezethetnek, ami a csoport szétesését eredményezheti. Ezzel szemben a konstruktív konfliktus a szervezet fejlődését eredményezheti, növeli a kreativitást és az egyéni produktivitást. A konstruktív versengés következtében az egyén motiváltabb lesz arra, hogy kihívások elé nézzen, nő a versengő felek közötti együttműködés és erősebb lesz az elkötelezettség a szervezet iránt, azonban a különböző stílusú és korosztályba tartozó személyek között könnyen destruktív folyamattá alakulhat.

Újabb vezetői kihívást jelent a különböző korcsoportok együttmüködésének elérése, valamint a generációs problémákból eredő konfliktusok kezelése. Westerman és Yamamura (2007) szerint a generációk közötti konfliktust elsősorban a kommunikációs stílus különbségei okozzák. A differenciából adódóan az adott szituációt különböző módon értelmezik és ebből kifolyólag a különböző nemzedék tagjai között nézeteltérés alakul ki. Egyértelmü Hochwarter et al. (2009) megállapítása, hogy a generációs konfliktusok egyértelműen kapcsolódnak a munkahelyi feszültséghez és a munkahelyi elégedetlenséghez. Smola és Sutton (2002) úgy véli, az értékek meghatározzák, mit gondolnak az emberek alapvetően helyesnek vagy rossznak, tehát a generációk érték különbségei konfliktust eredményezhetnek, azonban a munkavállalók értékei érettségüknél fogva változnak.

Singh (2014) szerint a különböző generációk között leggyakrabban a tudásmegosztás területén alakul ki konfliktus, tekintettel a korcsoportok különböző gondolkodásmódjára, hozzáállására, viselkedésére és értékrendjére, továbbá növeli a szakadékot a generációk között a fiatal nemzedék tagjainak rugalmassága és kiváló technikai ismerete. Bencsik és Machova (2016) szerint a boomerek inkább elkerülik konfliktust, nem foglalkoznak vele, amely abból eredeztethető, hogy hajlandóak áldozatvállalásra és képesek a változásokat is könnyen elfogadni (Kupperschmidt, 2000; Crampton Hodge, 2007). Az X generáció tagjai törekednek a kompromisszumra, számukra konfliktushelyzetben is fontos az egyensúly. A fiatalabb nemzedék tagjai alapvetően eltérő viselkedési stílust képviselnek a konfliktusokban. Az Y generáció a tipikus ellenálló, akik különösen érvekkel próbálják megoldani a helyzetet (Bencsik - Machova, 2016). Olšovská et al., (2015) szerint viselkedésük negatív oldalát erősíti, hogy nem tolerálják a kritikát vagy ellentmondást, akár vezetőikkel szemben sem, amely mögött a túlzott önbizalom és karriervágy húzódhat meg. A $\mathrm{Z}$ generációsok tipikusan provokátor stílussal jellemezhetőek, akik nem törekednek a konfliktusok megoldására, gyakran agresszívan reagálnak. Kutatások szerint a legközelebbi két generáció tud legkevésbé együttműködni, az Y generáció képes együtt dolgozni az $X$ generációval a közös célok elérése érdekében, de a $Z$ generáció egyedül akarja elérni a sikert, amely gyakran okoz konfliktust kapcsolatukban (Broennimann, 2017).

Összegzésül a konfliktusok egyaránt lehetnek hasznosak és károsak is. A konfliktusok pozitív vagy negatív hatást gyakorolnak ránk vagy a szervezetre, előjelük csakis attól függ, a vezetők és munkatársak tudják-e helyesen kezelni azokat, valamint képesek-e a megfelelő módszert megtalálni és adaptálni az adott szituációra. Vállalati szintü konfliktuskezelés során a vezetők szerepe megkérdőjelezhetetlen. A vezetőkön múlik, hogy a konfliktusok elősegítik vagy hátráltatják a szervezeti célok elérését, figyelembe véve az egyén, a csoport és a szervezet érdekeit.

\section{A kutatási hipotézisei}

\section{H1: A különböző nemzedékek együttes munkahelyi jelenléte generációk közötti konfliktusokat generál.}

A generációs kutatások többsége a jelenlegi munkaerőpiaci helyzetet problémaként értékeli, mivel egyszerre több generációnak kell együttmüködnie a munkahelyeken (Meretei, 2017; Messara et al., 2016), azonban a kutatók ritkábban foglalkoznak a különböző korcsoportok kooperációjának pozitív eredményeivel (Bencsik et al., 2016). A témakörrel foglalkozó kutatások többsége a munkahelyi konfliktusok 
kialakulásának egy részét generációs tényezőkre vezeti vissza (Messara et al., 2016; Smola - Sutton, 2002), valamint a jelenlegi munkaerö-piaci helyzetet együttmúködési diszharmóniaként értékeli (Becton et al., 2014). Az elméletek kiinduló pontja a generációk jelentősen eltérő munkahelyi attitüdjei, konfliktuskezelési stílusa (Neil, 2010; Soós, 2008; Kupperschmidt, 2000). A kutatók úgy értékelik, hogy az eltérő lojalitás, karriervágy, munkavégzési stílus összeegyeztethetősége a nemzedékek között problémás, az interakciók generációk közötti konfliktusok kialakulásához vezetnek (Elida-Tomita, 2010; Makra et al., 2012; Westerman - Yamamura, 2007).

\section{H2: A munkahelyi konfliktusok eltérő értékrendből alakulnak ki.}

Több kutatás foglalkozik azzal a kérdéssel, hogy az értékrendi jellemezők generációs vagy életkori sajátosságok. A legtöbb kutatás szerint (Westerman - Yamamura, 2007; Bencsik et al., 2016; Singh, 2014) a konfliktusok kialakulásnak egyik legmeghatározóbb tényezője az értékrendi különbség. Egyes kutatók szerint a generációk által elfogadott értékek különböznek (Messara et al., 2016; Shragay - Tziner, 2011), másrészről az életkor előrehaladásával ezek az értékek változhatnak is (Smola - Sutton, 2002), azaz generáción belül is jelentős különbségek lehetnek. A kutatások eredményei hasonlóak abban, hogy a konfliktusok kialakulásában az értékrendi különbség meghatározó, de jelentősen különböznek abban, hogy az értékrendi különbségből kialakuló konfliktus generációs tényezőként definiálható-e.

\section{H3: A fiatal munkavállalók a személyes visszajelzést és a munkavégzésüket támogató egyéni \\ figyelmet fontosabbnak ítélik, mint az idősebb munkavállalók.}

Kutatások szerint a boomerek és az X generációs munkavállalók önállóbbak a munkavégzés során (Crampton - Hodge, 2007), míg a fiatalabb generáció tagjai sokkal inkább igénylik a mentorálást, a személyes visszajelzésen alapuló kommunikációt (Neil, 2010). Az Y és Z generáció tagjai szeretik az olyan munkahelyi környezetet, ahol személyes megnyilvánulásra nyílik lehetőségük, teljesítményük folyamatosan és nyilvánosan kerül elismerésre, ennek hiányában könnyen konfliktushelyzet alakulhat ki körülöttük (Elmore, 2014; Zubány, 2008).

\section{Anyag és módszer}

\section{Alkalmazott kutatási módszerek}

A kutatás szekunder és primer módszerek használatára épült. A szekunder kutatás keretében a témakör jelentösebb szakirodalmát dolgoztuk fel. Kvantitatív eszközként kérdőíves felmérést készítettünk. A kérdőív összeállításánál, a kérdések megfogalmazásakor célunk volt, hogy azokat valamennyi válaszadó értelmezni tudja, munkavégzési területtől, beosztástól és munkakörtől függetlenül, ezáltal ne korlátozzuk a potenciálisan beérkező válaszok számát. A mintavétel nem véletlenszerủ módszerrel történt, emellett felmérésünk nem tekinthető reprezentatívnak (Sajtos
- Mitev, 2007). A kutatás kérdőívét online felületen tettük közzé 2017 decemberében, amelyre összesen 405 válasz érkezett, amelyből 395 kérdőívet minősítettünk értékelhetőnek. Adatfelvételünk 32 kérdést tartalmazott, amelyek többségénél zárt, feleletválasztós kérdéstípust alkalmaztunk. Az adatgyüjtés hitelességét növelve több esetben a kitöltők rendelkezésére állt „egyéb” válaszadási lehetőség is, a választási alternatívák pontosítása és saját véleményük kifejtése érdekében.

Sajtos és Mitev (2007) alapján az adatok értékelése leíró statisztikai módszerekkel történt, a kapott adatokat grafikusan ábrázoltuk és elemeztük. A háttérváltozók és az egyes válaszok közötti összefüggések kimutatása érdekében kereszttábla-elemzést végeztünk. A változók közötti összefüggések statisztikai szignifikanciájának mérésére $(\mathrm{p}<5 \%)$ Pearson-féle Khi négyzet $(\chi 2)$ próbát alkalmaztuk, a kapcsolatok szorosságának a megállapítására a Cramer-féle szorossági együtthatót számítottuk, továbbá egyszempontos varianciaanalízist használtunk.

\section{A vizsgált minta összetétele}

A kutatás célcsoportjának a felmérés időszakában az aktív foglalkoztatottakat választottuk, akik vállalkozások alkalmazottai vagy vezetôi voltak. A válaszadók demográfiai összetételét a 2. táblázat mutatja be. A táblázat adatai alapján látható, hogy a munkaeröpiacon jelenleg aktív generáció tagjai vettek részt a felmérésben. A válaszadók $65 \%$-a nő és $35 \%$-a férfi. Az iskolázottság esetében is törekedtünk arra, hogy valamennyi képzési szint munkavállalói részt vegyenek kutatásunkban.

2. táblázat $A$ vizsgált minta demográfiai összetétele, \% $(n=395)$

\begin{tabular}{|c|c|}
\hline Megnevezés & Megoszlás (\%) \\
\hline \multicolumn{2}{|c|}{ Nem } \\
\hline férfi & 35,0 \\
\hline nö & 65,0 \\
\hline \multicolumn{2}{|c|}{ Iskolai végzettség } \\
\hline felsőfokú & 48,7 \\
\hline gimnázium & 23,7 \\
\hline szakközépiskola & 17,8 \\
\hline szakiskola & 4,2 \\
\hline általános iskola & 5,6 \\
\hline \multicolumn{2}{|c|}{ Munkakör besorolása } \\
\hline szellemi & 79,9 \\
\hline fizikai & 20,1 \\
\hline \multicolumn{2}{|c|}{ Generációbesorolás } \\
\hline Boomer & 10,7 \\
\hline $\mathrm{X}$ generáció & 31,1 \\
\hline Y generáció & 40,7 \\
\hline Z generáció & 17,5 \\
\hline
\end{tabular}

Forrás: szerzők saját adatgyűjtése

A vizsgált mintában többségében szellemi (79,9\%) és kisebb részt fizikai munkakörben $(20,1 \%)$ foglalkoztatott 
munkavállalók vettek részt. A vállalatméret szerinti differenciálást a foglalkoztatott létszám szerint végeztük el, a válaszadók legnagyobb arányban (63,3\%) nagyvállalatoknál foglalkoztatott személyek. A válaszadók 10,7\%-a boomer és 31,1\%-a az X generáció tagja, 40,7\%-a Y, míg 17,\%-a Z generációs.

\section{Eredmények és értékelésük}

\section{Konfliktusok megjelenése a szervezetekben}

Számos kutatás szervezeti problémaként emeli ki a különböző generációk munkahelyi együttmüködésének diszharmóniáját (Becton et al., 2014). A kutatásunkban mind a négy aktív generáció jelen volt. Vizsgáltuk a szervezetek munkavállalóinak életkor szerinti megoszlását, amely alapján három csoportba soroltuk a munkavállalókat. A megkérdezett munkavállalók 46,6\%-a úgy ítélte meg, hogy munkahelyükön valamennyi generáció közel megegyező arányban dolgozik, míg 38,1\%-a úgy ítélte meg, hogy jelentős korkülönbség alakult ki a munkahelyükön, továbbá a kutatásba bevont személyek 15,3\%-a szerint a munkahelyi közösséget egy generáció meghatározó többsége alkotja. A konfliktus gyakoriságát generációk szerint a 3. táblázat mutatja be.

3. táblázat A generációs konfliktus gyakorisága, \% $(n=395)$

\begin{tabular}{|l|c|c|c|c|}
\hline \multirow{2}{*}{ Megnevezés } & \multicolumn{4}{|c|}{ Korosztály } \\
\cline { 2 - 5 } & Boomer & $\begin{array}{c}\text { X gene- } \\
\text { ráció }\end{array}$ & $\begin{array}{c}\text { Y gene- } \\
\text { ráció }\end{array}$ & $\begin{array}{c}\text { Z gene- } \\
\text { ráció }\end{array}$ \\
\hline $\begin{array}{l}\text { Ritkábban, } \\
\text { mint havonta }\end{array}$ & 63,2 & 76,4 & 56,2 & 53,2 \\
\hline $\begin{array}{l}\text { Havonta 1-2 } \\
\text { alkalommal }\end{array}$ & 10,3 & 2,7 & 8,3 & 0,0 \\
\hline $\begin{array}{l}\text { Hetente 1-2 } \\
\text { alkalommal }\end{array}$ & 15,5 & 8,2 & 14,6 & 8,1 \\
\hline $\begin{array}{l}\text { Hetente 3-4 } \\
\text { alkalommal }\end{array}$ & 0,0 & 4,5 & 2,1 & 14,5 \\
\hline Naponta & 10,1 & 8,2 & 18,8 & 24,2 \\
\hline
\end{tabular}

Forrás: szerzők adatgyűjtése

A különböző generációs csoportba tartozó munkavállalók körében eltérő arányú konfliktusgyakoriságot azonosítottunk. A konfliktusok gyakoriságát elemezve az egyes generációs csoportok és a konfliktusok gyakorisága között szignifikáns eredményt tapasztaltunk (Pearson $K h i^{2}=$ 43,022; $d f=12 ; P=0,000 ; C=0,201)$, tehát a generációk ebben az aspektusban különböznek egymástól. A Z generációs munkavállalók közel fele $(46,8 \%)$ heti rendszerességgel kerül konfliktushelyzetbe a munkahelyén, míg az $\mathrm{X}$ generációs személyeket tekinthetjük leginkább együttműködőnek, mivel a generáció tagjainak többsége $(76,4 \%)$ ritkábban, mint havonta kerül nézeteltérést eredményező szituációba. A fiatalabb nemzedék (Y és Z generáció) tagjai a kialakult konfliktusokat jellemzően generációs okokra vezették vissza, ezzel szemben az X és a Boomer generáció tagjai szerint a konfliktusok az adott életszakasz természetes viselkedési formái. A konfliktusok megítélése szempontjából különbséget tehetünk konstruktív és destruktív konfliktus között. A konstruktív konfliktus alapvetően hozzájárul a szervezeti teljesítmény növekedéséhez, tehát szervezetfejlesztési eszközként is definiálható, míg a destruktív konfliktus a szervezet szempontjából romboló hatású (Elida-Tomita, 2011). Konfliktuskutatás szempontjából a két irány elkülönítése és elemzése szükséges, mivel a két eltérő szituációban az egyének szervezeti viselkedése és válaszreakciói jelentősen különbözhetnek (4. táblázat). A generációk tagjai többnyire elismerik a konfliktusok előnyeit és hátrányait, azonban életkori sajátosságok is kirajzolódnak az adatok alapján. A Y és Z generációsok inkább negatív, míg a boomerek és az Y nemzedék tagjai pozitív jelenségként tekintenek a konfliktushelyzetre.

4. táblázat A konfliktusok megítélése generációs nézőpont alapján, \% $(n=395)$

\begin{tabular}{|l|c|c|c|c|}
\hline \multirow{2}{*}{ Állítás } & \multicolumn{4}{|c|}{ Korosztály } \\
\cline { 2 - 5 } & Boomer & $\begin{array}{c}\text { X gene- } \\
\text { ráció }\end{array}$ & $\begin{array}{c}\text { Y gene- } \\
\text { ráció }\end{array}$ & $\begin{array}{c}\text { Z gene- } \\
\text { ráció }\end{array}$ \\
\hline $\begin{array}{l}\text { A konfliktus } \\
\text { negatív } \\
\text { jelenség, amit } \\
\text { kerülni kell. }\end{array}$ & 0,0 & 2,7 & 16,7 & 14,5 \\
\hline $\begin{array}{l}\text { A konfliktusok } \\
\text { egyaránt } \\
\text { lehetnek } \\
\text { hasznosak és } \\
\text { károsak is. }\end{array}$ & 84,2 & 78,2 & 72,9 & 85,5 \\
\hline $\begin{array}{l}\text { Pozitív } \\
\text { jelenségként } \\
\text { tekintek a } \\
\text { konfliktusra. }\end{array}$ & 15,8 & 19,1 & 10,4 & 0,0 \\
\hline
\end{tabular}

Forrás: szerzők adatgyűjtése

A konfliktusok hatására különböző munkavállalói reakciókat tapasztaltunk. A tartósan fennálló konfliktus hatására teljesítménycsökkenés $(82,5 \%)$, munkahelyváltás (68,9\%), érzelmi reakciók (71,8\%) megjelenése azonosítható. A válaszreakció típusában az egyes generációk eltérő módon viselkednek, a munkateljesítmény csökkenése és a gyors munkahelyváltás a fiatal generációra (Y és Z) jellemző, míg az érzelmi reakciók megjelenése a Boomer és az X nemzedék tagjainál azonosítható. A különböző generációba tartozó munkavállalók és a konfliktusok megítélése között szignifikáns kapcsolatot tapasztaltunk (Pearson $\left.K h i^{2}=31,041 ; d f=6 ; P=0,000 ; C=0,209\right)$, kutatásunk alapján a fiatalabb egyének károsabb tényezőként élik meg a konfliktust, míg az életkor előrehaladásával tapasztalható a konfliktus konstruktív hatásként történő értelmezése. A konfliktust destruktív érzésként definiáló munkavállalók esetében meghatározó következmény a munkahelyi teljesítménycsökkenés $(91,7 \%)$, míg a konfliktust konstruktív tényezőként történő értelmezés esetében már csak a munkavállalók 78,6\%-ánál párosult teljesítményszint-csökkenéssel (Pearson Khi $i^{2}=45,424 ; d f=4 ; P=0,000 ; C=0,253$ ). 
A konfliktus megítélését megvizsgáltuk a válaszreakciók megnyilvánulása, valamint a munkahelyváltási hajlandóság szempontjából, amely során szignifikáns összefüggést nem tapasztaltunk, viszont az adatok alapján megállapítható, hogy a konfliktust destruktív jelenségként értékelő személyek intenzívebb érzelmi megnyilvánulással jellemezhetőek, és jelentősebb a munkavállalók felmondási hajlandósága is, azaz a probléma felmerülését követően gyorsan reagálnak, míg a konstruktív személyek inkább magukba fojtják a tervezett reakciójukat és a munkahelyváltáshoz is megfontoltabban állnak hozzá.

\section{Konfliktusokat meghatározó tényezők}

\section{A munkavállalói magatartás tényezői}

A generációk között tapasztalható destruktív konfliktusokban számos emberi és szervezeti hatás is szerepet játszik. Munkahelyi környezetben egymástól eltérő gondolkodásmóddal, készségekkel, képességekkel, viselkedési stílussal rendelkező munkatársak eredményes együttműködését kell megvalósítani, amely a nem megfelelö munkavállalói összetétel esetén interperszonális konfliktusok kialakulásához vezethet. A válaszadók különböző viselkedési tulajdonságokat értékeltek abból a szempontból, hogy a különböző viselkedési minták milyen mértékben indukálták a destruktív konfliktust a munkahelyeken. A válaszadók 20 különböző viselkedési tulajdonságot minősítettek, amelyek közül mind a négy generáció preferenciájában megjelenő nyolc legjellemzőbb tulajdonságot vettünk számításba az elemzés során. A kapott válaszokat a Likert-skála pontértékeinek átlaga alapján rangsoroltuk, amelyet az 5. táblázat mutat be.

A kutatásba bevont négy generációnál az eltérő értékrend bizonyult meghatározó tényezőnek az inter- perszonális konfliktusokban. Egyetértünk több szerző (Mannheim, 1952; Soulez - Soulez, 2011; Joshi et al., 2010; Kertzer, 1983) kutatásaival, akik szerint az egyéni értékrend változását számos szociokulturális szempont is befolyásolhatja (pl.: család, vallás, a lakóhely, gazdasági fejlettsége, munkahely), így a generációk szerinti tipizálás nem lehet alapja a munkahelyi konfliktusoknak. A boomerek a munkahelyi versengést negatívan élték meg, úgy vélekednek, hogy e munkahelyi jelenség jelentős szerepet játszik a konfliktusokban, míg velük szemben a fiatalabbak a versenyt, a munkahelyi környezet természetes tulajdonságának tekintik. Az értékrendi különbségekböl eredeztethető problémák a női válaszadók körében határozottabban jelentek meg, míg a fizikai dolgozók toleránsabbaknak bizonyultak az értékrendi különbségekkel szemben.

A generációs csoportok körében ANOVA-vizsgálattal teszteltük a csoportok által adott vélemények heterogenitását, azaz arra kerestük a választ, hogy az egyes tulajdonságok megítélésében hasonlóan vagy különbözően vélekednek az egyes generációk. A varianciaanalízis eredménye alapján az értékrendi különbség esetében nem kaptunk szignifikáns eredményt, amely azt jelzi, hogy a vizsgált generációs csoportok hasonlóan gondolkodnak a konfliktust kiváltó legmeghatározóbb tényezőről. A válaszadók szerint - generációtól függetlenül - a konfliktusok legjellemzőbben az eltérő értékrend miatt alakultak ki. A vizsgált generációk között szignifikáns különbséget három viselkedési tulajdonság mentén tapasztaltunk, eltérő módon élik meg a munkahelyi versengést, a munkatársak közötti kommunikációt és az elöítéletekről alkotott elképzelésük is eltérő.

A szervezeti kommunikációs tényezők

A vállalatok belső klímájának alakításában a szervezeti

5. táblázat A generációk közötti konfliktusokat kialakító tényezők ( $n=395)$

\begin{tabular}{|l|c|c|c|c|c|c|c|c|}
\hline \multirow{2}{*}{ Megnevezés } & \multicolumn{2}{|c|}{ Boomer } & \multicolumn{2}{c|}{ X generáció } & \multicolumn{2}{c|}{ Y generáció } & \multicolumn{2}{c|}{ Z generáció } \\
\cline { 2 - 9 } & Rangsor & Átlag & Rangsor & Átlag & Rangsor & Átlag & Rangsor & Átlag \\
\hline Eltérö értékrend & $\mathbf{1 .}$ & $\mathbf{4 , 2 1}$ & $\mathbf{1 .}$ & $\mathbf{4 , 0 4}$ & $\mathbf{1 .}$ & $\mathbf{3 , 9 2}$ & $\mathbf{1 .}$ & $\mathbf{4 , 2 3}$ \\
\hline $\begin{array}{l}\text { Elismerésért folyó } \\
\text { versengés }\end{array}$ & 2. & 3,87 & 6. & 3,62 & 8. & 3,13 & 7. & 3,50 \\
\hline $\begin{array}{l}\text { Nem megfelelö } \\
\text { munkatársi } \\
\text { kommunikáció }\end{array}$ & 3. & 3,87 & 5. & 3,63 & 2. & 3,92 & 2. & 3,94 \\
\hline Eltérö munkamorál & 4. & 3,76 & 2. & 3,79 & 4. & 3,83 & 5. & 3,92 \\
\hline Eltérő motiváció & 5. & 3,68 & 3. & 3,74 & 6. & 3,69 & 3. & 3,94 \\
\hline $\begin{array}{l}\text { Önértékelési } \\
\text { különbségek }\end{array}$ & 6. & 3,68 & 7. & 3,50 & 7. & 3,36 & 8. & 3,21 \\
\hline $\begin{array}{l}\text { Előítéletek, } \\
\text { hibás személyészlelés }\end{array}$ & 7. & 3,53 & 8. & 3,38 & 3. & 3,87 & 6. & 3,79 \\
\hline $\begin{array}{l}\text { Munkavégzési sebesség/ } \\
\text { nutenzitásbeli } \\
\text { különbségek }\end{array}$ & 8. & 3,47 & 4. & 3,68 & 5. & 3,78 & 4. & 3,94 \\
\hline
\end{tabular}

Forrás: szerzők adatgyűjtése 
kommunikáció kulcstényező (Drenth et al., 1998), mivel a belső kommunikációs rendszer kiépítése és müködtetése a vállalati célok megvalósítása érdekében elkerülhetetlen. Az eredményes munkavégzés feltételei nem alakíthatóak ki hatékony információáramlás nélkül. Figyelembe véve a különböző generációk munkahelyi jelenlétét, a munkavállalók információfogyasztásának szokásai is megváltoztak. A külső kommunikációs rendszerek kiépítéséhez hasonlóan a vezetőknek szegmentálniuk szükséges az egyes „információfogyasztó” célcsoportokat, különböző munkavállalói jellemzők alapján. Az eredményes müködés nélkülözhetetlen feltétele, hogy a kommunikációs folyamatban részt vevő szereplők és szervezeti szintek között biztosított legyen az optimális mennyiségű és minőségü információ áramlása (Ivancevich - Matteson, 2002). Ha az információáramlás és annak tartalma nem megfelelő a különböző munkahelyi célcsoportok számára, akkor várhatóan kommunikációs zavarok alakulnak ki, amelynek eredménye a munkahelyi konfliktus (Spaho, 2013). Kutatásunkban elemeztük a kommunikációs diszfunkciók konfliktusokra gyakorolt hatását, amelyet a 6. táblázat mutat be.

6. táblázat Kommunikációs tényezők megítélése $(n=395)$

\begin{tabular}{|l|c|c|}
\hline Megnevezés & Átlag & Szórás \\
\hline Visszajelzés hiánya & 4,18 & 1,17 \\
\hline Információhiány & 3,87 & 0,93 \\
\hline $\begin{array}{l}\text { Az információ téves értelmezése, } \\
\text { félreértések }\end{array}$ & 3,21 & 1,13 \\
\hline Nem egyértelmű megfogalmazás & 2,65 & 0,92 \\
\hline $\begin{array}{l}\text { Nem releváns vagy helytelen } \\
\text { információ }\end{array}$ & 2,46 & 0,96 \\
\hline Szükségesnél több információ & 1,75 & 0,72 \\
\hline
\end{tabular}

Forrás: szerzők adatgyűjtése

A kommunikációs problémák közül a személyes viszszajelzés hiánya okozott legnagyobb mértékben konfrontációt a munkahelyeken. Neil (2010) kutatásai is alátámasztják, hogy már az X generáció is megtanulta, és ezáltal elvárja a folyamatos visszajelzést, ennek hiánya viszont a bizonytalanság érzését erősíti meg a munkavállalókban. Feltételezésünk alapján e tényező kiemelkedő jelentőségü a szervezetek kommunikációs rendszerének müködtetésében, mivel információátadó szerepén túlmenően motivációs hatása is erőteljes. A megfelelően végrehajtott feedbackfolyamat javíthatja a perszonális kapcsolatokat és a munkatársak munkahelyi elégedettségére is pozitív hatást gyakorol. Azonban emberi tulajdonságainkból adódóan a visszacsatolásra különböző módon reagálhatunk, így a vezetői kommunikáció motivációs szerepe és ebből adódóan konfliktuscsökkentő hatása is jelentős, amelyet Stam et al. (2016) kutatása is megerősít. A vizsgált személyek esetében az alacsony szintű információs ellátottság is jelentősen hozzájárult a személy- és szervezetközi ellentétek kialakulásához. Az információhiányt részben tekinthetjük szubjektív megítélésnek is, mivel a munkavállalói magatartást befolyásolhatja az egyén információs igénye. A konfliktusok gyökérproblémájának is tekinthetjük a munkavállalók ala- csony információs ellátottságát, mivel a dolgozók általában hiányérzetként tekintenek erre a helyzetre. Elemeztük az információtöbblet hatását is, amely esetben azt tapasztaltuk, ha a munkavállalókat a szükségnél több információval látjuk el, az számukra elenyésző mértékben eredményezett negatív helyzetet. A további vizsgált tényezők, mint a félreértések, a nem egyértelmü vagy helytelen megfogalmazások konfliktusalakító szerepe elhanyagolható. Varianciaanalízis (ANOVA) alkalmazásával megállapítottuk, hogy a vizsgált generációs csoportok különböző módon vélekednek a kommunikációs okokra visszavezethető konfliktusok okairól $(S S=11,469 ; d f=3 ; M S=3,823 ; F=4,592 ; P=0,004)$. A Boomer generáció tagjai - visszajelzés hiánya kivételével - alacsonyabb értékekkel minősítették a kommunikációs faktorokat, mint az Y és $Z$ generációs munkavállalók. Ezzel szemben a fiatalabb munkavállalók hangsúlyosabban ítélték meg a kommunikációs konfliktusokat, amelyek közül az információ eltérő értelmezéséből adódó konfrontációt tekintik meghatározó problémának, amelyet Sharagy és Tziner (2011) generációs jelenségként értelmezett írásában.

\section{A szervezeti felépítésből eredő tényezők}

A szervezeti felépítésből származó hiányosságok és problémák olyan tényezők, amelyek a szervezet potenciális konfliktusforrásai lehetnek. Kutatásunk során fontosnak tartottuk munkavállalói szempontból a szervezeti struktúra nem megfelelőségéből adódó konfliktus „ösztönző" hatását is elemezni (7. táblázat) és feltárni a generációs különbségekből származó sajátosságokat.

\section{7. táblázat Szervezeti struktúrából eredő konfliktusok} $(n=395)$

\begin{tabular}{|l|l|l|}
\hline Megnevezés & Átlag & Szórás \\
\hline Magas létszámú szervezeti egységek & 4,21 & 1,55 \\
\hline $\begin{array}{l}\text { Szervezeti egységek közötti } \\
\text { összehangolás hiánya }\end{array}$ & 4,01 & 1,57 \\
\hline $\begin{array}{l}\text { Különböző munkavégzési } \\
\text { körülmények a szervezeti egységek } \\
\text { között }\end{array}$ & 3,47 & 1,56 \\
\hline $\begin{array}{l}\text { Különbségek a személyes } \\
\text { munkavégzés során használt } \\
\text { eszközök minőségében }\end{array}$ & 2,90 & 1,37 \\
\hline Szervezeti egységek közötti távolság & 2,55 & 1,37 \\
\hline $\begin{array}{l}\text { Szervezeti átalakítások, folyamatos } \\
\text { változások }\end{array}$ & 2,39 & 1,22 \\
\hline
\end{tabular}

Forrás: szerzők adatgyűjtése

A szervezetek átalakulásának trendje jelenleg egyszerübb, laposabb, kevesebb szervezeti egységet, de magasabb munkavállalói létszámmal gazdálkodó rendszerek kialakításának irányába mutat, amelyet Meretei (2017) is azonosított kutatásában. Az ilyen irányú szervezeti változások előnyként magukban hordozzák a döntési rugalmasságot és a szervezetek piaci reagálásának felgyorsulását. A folyamat hátrányaként ugyanakkor tapasztalható - hatékony szervezetmenedzsment-módszerek alkalmazása nélkül - a szervezeti egységre jutó alkalmazotti létszám emelkedéséből 
származó konfliktusgyakoriság növekedése. Kutatásunk eredménye alátámasztja e szervezetfejlesztési trend negatív hatását, mivel a munkavállalók indukciós hatásként értékelték a magas létszámú szervezeti egységek müködéséből eredő problémákat. E problémát kiemelkedően a Boomer és az X generáció tagjainál tapasztaltuk, szemben a fiatal generáció tagjaival, akik jelentősebb problémaként a munkavégzés során használt eszközök minőségét fogalmazták meg, amely jelenség az Y és a Z generáció ,technológiaörült" értékrendi jellemzőire vezethetők vissza. A megkérdezett munkavállalók a következő meghatározó szervezeti problémaként az egységek közötti összehangolás hiányát említették. E probléma abból a szervezeti müködési sajátosságból adódhat, hogy általában a munkahelyi apparátus felépítése funkcionális elvek mentén történik, azaz egy-egy folyamatszakaszra specializálódott szervezeti egységek jönnek létre, amelyek vezetése lineárisan történik. A vállalati gyakorlatban jellemző mátrixszervezeti felépítés egyik fontos előnye az erőforrások kihasználásának javítása és a szervezeti egységek közötti munkaszervezés hatékonyságának növelése. Azt tapasztaltuk, hogy az egységek közötti összehangolás hiánya mind a szervezeti, mind az interperszonális konfliktusok kialakulását jelentősen befolyásolják $(S S=11,521 ; d f=3 ; M S=3,321 ; F=4,284 ; P=0,000)$. Továbbá elemeztük a szervezeti méret és a konfliktusgyakoriság öszszefüggését, amely alapján azonosítottuk, hogy a szervezeti méret növekedésével, csökken a belső konfliktusok gyakorisága $\left(K h i^{2}=41,101 ; d f=12 ; p=0,000\right)$. E jelenség annak tulajdonítható, hogy a nagyvállalatokat általában folyamatorientált gondolkodás jellemzi, amely a szervezeti egységek szinergikus együttmüködését is javítja.

A megfelelő színvonalú szervezetfejlesztés hiányában a munkahelyeken belüli konfliktusok növekedhetnek. A strukturális tényezők mellett a vezetési problémákra visszavezethető konfliktusfaktorokat is elemeztük (8. táblázat).

8. táblázat Vezetési hiányosságokból adódó konfliktusok $(n=395)$

\begin{tabular}{|l|c|c|}
\hline Megnevezés & Átlag & Szórás \\
\hline Munkatársak eltérö terheltsége & 4,21 & 0,97 \\
\hline $\begin{array}{l}\text { Teljesítmény és ösztönzés közötti } \\
\text { aránytalanság }\end{array}$ & 4,21 & 1,19 \\
\hline Egyéni túlterheltség & 4,10 & 1,02 \\
\hline Gyakori többletmunka, túlóra & 4,00 & 1,06 \\
\hline $\begin{array}{l}\text { Túl kevés idő áll rendelkezésre } \\
\text { a feladatok ellátásához }\end{array}$ & 3,88 & 1,17 \\
\hline $\begin{array}{l}\text { Feladat- és felelösségi körök } \\
\text { tisztázatlansága }\end{array}$ & 3,84 & 1,18 \\
\hline $\begin{array}{l}\text { Elismerések, fizetések és jutalmak } \\
\text { egyenlőtlen elosztása }\end{array}$ & 3,49 & 1,31 \\
\hline $\begin{array}{l}\text { Változó elvárások az alkalmazottak- } \\
\text { kal szemben }\end{array}$ & 3,42 & 1,40 \\
\hline Értekezletek hiánya & 3,07 & 1,42 \\
\hline
\end{tabular}

Forrás: szerzők adatgyűjtése

A megkérdezett munkavállalók meghatározó problémaként a nem egyforma munkaterheltséget, a teljesítmény és ösztönzés közötti aránytalanságot, valamint az egyéni túlterheltséget nevezték meg. A vezetési, szervezési diszfunkciók megítélésében a generációs hatás érzékelhető. A vizsgált korosztályok között szignifikáns különbséget tapasztaltunk az egyéni túlterheltség, az értekezletek hiánya és az ösztönzés aránytalansága tekintetében. Az Y és $Z$ generáció kevésbé tartja problémának a fizetési különbségeket, szemben az idősebb korosztály tagjaival, amíg teljesítményalapon történik a javadalmazás. A fiatal generáció kevésbé tolerálja a szenioritáson alapuló bérezést, amely azt jelenti, hogy a feladat szakszerü végrehajtásának függvényében jogosult a jutalomra, függetlenül a munkaerő-piaci tapasztalat időtartamától. Kutatásunk során azt tapasztaltuk, hogy a fiatalabb munkavállalók hiányolják a tartalmas értekezleteket, mivel a munkahelyi témák személyes megvitatásának hiánya nagyobb problémát jelentett számukra $(\mathrm{SS}=24,888 ; \mathrm{df}=3 ; \mathrm{MS}=8,296$; $\mathrm{F}=4,218 ; \mathrm{P}=0,006$ ), mint az idősebb munkavállalóknak, tehát a fiatalok a vezetőkkel történő személyes kontaktust jobban igénylik. A kutatási eredmény összecseng Neil (2010) megállapításaival, aki szerint a fiatal generáció tagjai kapcsolatorientáltak, törekednek a vezetőikkel a személyes kapcsolatok kialakítására. Így számukra az értekezletek megfelelő alkalomnak mutatkoznak a vezetővel történő találkozásra és az egyéni tehetség kibontakoztatására. E dinamizmus okozhat konfliktust, tekintettel az X generációs vezetőkre, akik ezzel szemben a függetlenséget és az egyéni munkát preferálják.

\section{A konfliktusok kezelése}

A munkahelyi konfliktuskezelés során a vezetőkre nagy felelősség hárul. A konfliktusok elmélyülése vagy nem megfelelő kezelése növelheti a munkatársak közötti nézeteltéréseket, a munkahelyi légkör romlását és az alkalmazottak teljesítményének csökkenését, amely végső esetben akár a munkaerő elvesztését is okozhatja. A vezetőknek törekedniük kell az optimális konfliktuskezelési megoldások alkalmazására, amely az egyéni, csoportos és szervezeti céloknak is megfelel. Kutatásunkban a vezetők konfliktuskezelési szerepvállalását elemeztük a beosztott munkavállalók nézőpontjából. A megkérdezett munkavállalók tapasztalata alapján a vezetők az esetek 56,8\%-ában semleges maradnak mindaddig, amíg a konfliktus nem rombolja a munkahelyi légkört, és nem megy a munka eredményességének rovására. A válaszadók $28,2 \%$-a szerint a vezetők egyáltalán nem avatkoznak be a konfliktusok megoldásába, hanem hagyják, hogy a beosztottak maguk oldják meg azokat. A beosztottak mindössze 15\%-a értékelte úgy, hogy felettese azonnal cselekszik, és próbál az egyéni és szervezeti érdekeknek megfelelő megoldást találni a kialakult helyzetre. A vezetői szerepvállalás és a vállalati méret között szignifikáns kapcsolatot tapasztaltunk, a vállalkozás létszámának növekedésével a vezetők szerepvállalása csökken a konfliktusok megoldásában (Pearson $K h i^{2}=23,579 ; d f=6 ; P=0,001 ; C=0,182$ ), amely magyarázható a nagyvállalati kultúrával és a fejlettebb képzési rendszerrel. A felsőfokú végzettségű női vezetők érzékenyebben viszonyulnak a konfliktushelyzetekhez, mivel a női vezetők intenzívebb szerepvállalást tanúsíta- 
nak a nézeteltérések megoldásában, mint a férfivezetők (Pearson $K h i^{2}=9,248 ; d f=2 ; P=0,010 ; C=0,162$ ). A válaszadók többsége további vezetői tulajdonságként elvárja felettesétől a kialakult konfliktushelyzetben, hogy igazságot szolgáltasson, továbbá az érintett felek egyenrangú meghallgatását, valamint a konfliktust okozó tények felismerését. A konfliktuskezelésben elvárt vezetői viselkedési stílus értékelését a 9. táblázat mutatja be.

9. táblázat A konfliktuskezelés során elvárt vezetői viselkedési formák $(n=395)$

\begin{tabular}{|l|l|l|}
\hline \multicolumn{1}{|c|}{ Megnevezés } & Átlag & Szórás \\
\hline $\begin{array}{l}\text { Személyeskedéstől mentes } \\
\text { viselkedés }\end{array}$ & 4,08 & 1,02 \\
\hline Öszinteség & 3,99 & 1,00 \\
\hline $\begin{array}{l}\text { Megoldás központú } \\
\text { konfliktuskezelés }\end{array}$ & 3,96 & 1,05 \\
\hline Empátia & 3,82 & 0,97 \\
\hline $\begin{array}{l}\text { Figyelem a helyzet pontos } \\
\text { megismerésére }\end{array}$ & 3,82 & 1,01 \\
\hline Kompromisszumra törekvés & 3,79 & 0,98 \\
\hline Nyíltság & 3,77 & 0,96 \\
\hline Megbocsátás & 3,56 & 0,92 \\
\hline Másik fél nézőpontjának elfogadása & 3,56 & 0,95 \\
\hline
\end{tabular}

Forrás: szerzők adatgyűjtése

A munkavállalók elsődlegesen a személyeskedésmentes viselkedést, az őszinteséget és a megoldásközpontú konfliktuskezelést várják el vezetőiktől, amelyekben a generációk hasonló módon gondolkodnak, azonban Slabbert (2004) szerint a fiatalabbakat a nagyobb fokú együttmüködés, míg a tapasztaltabb személyeket az alacsonyabb szintű együttmüködés jellemzi a problémamegoldás során. A konfliktuskezelési magatartás a fiatalabb és tapasztaltabb munkatársak esetén is eltérő. Csoportok közötti szignifikánsan különbséget tapasztaltunk az elfogadás $(\mathrm{p}=0,000)$, a nyíltság $(\mathrm{p}=0,000)$ és a megbocsátás $(\mathrm{p}=0,001)$ megítélésben. Az X generációsok számára e viselkedési formák fontosabbak, mint a többi generáció tagjainak, amely ellentmond Whitney et al. (2009) megállapításával, akik szerint a vizsgált generációt inkább a gyanakvás jellemzi. Az X generációs munkavállalók értékrendjében kiemelkedő jelentőségű a vezetők empatikus hozzáállása. A vezetői tulajdonságok nemek szerint megítélése jelentősen különböző, valamennyi viselkedési sajátosság esetén - egy tényezőtől eltekintve - szignifikáns eredményt kaptunk valamennyi tulajdonság esetében, amely alapján a női munkavállalók emberközpontú hozzáállása meghatározó. Míg a személyeskedéstől mentes viselkedés esetén a férfiak véleménye határozottabban megnyilvánult, ők e tulajdonságot lényegesen fontosabbnak tartják, amely a tényszerüség szerepének a felértékelődését jelenti a konfliktuskezelés folyamatában.

\section{Konklúzió}

Kutatásunk során megvizsgáltuk a munkahelyi konfliktusok kiváltó okait és a meghatározó munkahelyi konfliktusforrásokat. A következő szakaszban bemutatjuk a tanulmányunk elején megfogalmazott hipotézisek ellenőrzését:

\section{H1: A különböző nemzedékek együttes munkahelyi} jelenléte generációk közötti konfliktusokat generál.

A fiatalok a konfliktusokat negatívan élik meg, életkori sajátosságukból adódóan nem rendelkeznek hatékony konfliktuskezelési módszerekkel. A munkahelyi együttműködés szempontjából az idősebbeket a befogadó szemlélet jellemzi, míg a fiatalok az életkori különbségekre vezették vissza a konfliktusok kialakulását. A fiatalabb nemzedék tagjai a kialakult helyzetre generációs konfliktusként tekintettek, míg a boomer és az X generációs munkavállalók a munkahelyi stresszt és feszültséget emelték ki, amelynek következtében együttmüködési diszharmónia alakult ki a munkatársak között, generációtól függetlenül. Összefüggés-vizsgálattal megállapítottuk, hogy a munkahelyi konfliktusok gyakoriságában különböznek a generációk egymástól (Pearson Khí $\left.{ }^{2}=43,022 ; \mathrm{df}=12 ; \mathrm{P}=0,000 ; \mathrm{C}=0,201\right)$, amely azt jelenti, hogy a fiatalabb munkavállalókat intenzív konfliktuskörnyezet jellemez, szemben a boomer és az $\mathrm{X}$ generációs személyekkel. A generációk tagjai különböző módon ítélik meg a konfliktusok kialakulását, így kutatásunk nem támasztotta alá, hogy több generáció együttes munkahelyi jelenléte nemzedékek közötti konfliktust generált, így a megfogalmazott hipotézist elvetjük.

\section{H2: A munkahelyi konfliktusok eltérő értékrendböl alakulnak ki.}

ANOVA-vizsgálattal megállapítottuk, hogy a generációk között nincs szignifikáns különbség az eltérő értékrend munkahelyi konfliktusra gyakorolt hatásában. Megállapítható, hogy az interperszonális konfliktusok egyik meghatározó tényezője az eltérő értékrend, de az egyéni jellemvonások kialakulásában az életkori tényezőn túlmenően további szempontok is szerepet játszanak. Egyetértünk Smola és Sutton (2002) munkaérték-változás elméletével, hogy az egyéni értékek az életkor elörehaladásával változhatnak, így az azonos generációs csoportba tartozó személyek is rendelkezhetnek eltérö értékrenddel, amely a legjellemzőbb konfliktustényező, ennek eredménye alapján a hipotézist elfogadjuk.

\section{H3: A fiatal munkavállalók a személyes visszajelzést és a munkavégzésüket támogató egyéni \\ figyelmet fontosabbnak ítélik, mint az idősebb munkavállalók.}

A feltételezést elfogadjuk, mert a korosztályok különböző módon vélekednek a kommunikációs okokra visszavezethetö összeütközések okairól $(S S=11,469 ; d f=3 ; M S=3,823$; $F=4,592 ; P=0,004)$. A fiatal munkavállalók életében a kommunikációs eredetü konfliktusok meghatározóak. ANOVAvizsgálattal alátámasztottuk, hogy a fiatalabb munkaválla- 
lók igénylik a tartalmas értekezleteket, mivel a munkahelyi témák személyes megvitatásának hiánya nagyobb problémát okoz számukra $(S S=24,888$; $d f=3 ; M S=8,296 ; F=4,218$; $P=0,006)$, mint az idősebb munkavállalóknak, azaz a fiatalok a vezetőkkel történő személyes kontaktust is igénylik.

Kutatásunk alapján látható, hogy konfliktusok generációtól függetlenül, azonos és különböző életkorú munkavállalók között is kialakulhatnak. A konfliktusok kiváltó tényezőjeként elsődlegesen az eltérő értékrendet azonosítottuk, amely az életkor előrehaladásával változhat.

Az eredmények alapján úgy ítéljük meg, hogy a generációk közötti konfliktus vezetési és HR-funkciók alkalmazásproblémáira vezethető vissza. Gondolatunk megerősítését szolgálja, hogy a felmérésünkben a nagyvállalatok munkatársai alacsonyabb mértékü és gyakoriságú konfliktust tapasztaltak munkahelyükön. Tapasztalatunk alapján a nagyvállalatok hatékonyabb menedzsmentrendszereket müködtetnek, mint a kisvállalkozások. Kutatásunk alapján úgy értékeljük, hogy a vállalati gyakorlatban a destruktív konfliktus megjelenése mérsékelhető, ha az értékalapú kiválasztási és fejlesztési programokat beépítik a vezetők a HR gyakorlatába. Nagyvállalati környezetben általában természetesnek tekinthető, hogy a kiválasztási folyamat során a jelöltek szakmai kompetenciáinak értékelésénél túlmenően a humánkompetenciák objektív azonosítására is hangsúlyt fektetnek. Kis- és középvállalatok körében azonban kevésbé alkalmazott területek közé tartozik a soft-skillek objektív mérése és fejlesztése, amely a közös nyelv, a közös értékrendszer kialakításának meghatározó építőköve. Úgy gondoljuk, hogy már a munkaerőkiválasztás során meg kell teremteni a munkavállalóknak a szervezet küldetéséhez, stratégiájához az egyértelmü kapcsolódást, amely rövid távon csökkenti az interperszonális konfliktusok számát, hosszú távon pedig a fenntartható és versenyképes vállalati működést támogatja.

\section{Felhasznált irodalom:}

Bakacsi Gy. (2015): A szervezeti magatartás alapjai: Alaptankönyv Bachelor hallgatók számára. Budapest: Semmelweis Kiadó, p. 367. (ISBN: 978-963-331-313-8)

Becton, J. B. - Walker, H. J. - Jones, F. A. (2014): Generational differences in workplace behavior. Journal of Applied Social Psychology, 44 (3), p. 175-189. doi: 10.1111/ jasp.12208.

Bencsik, A. - Horváth-Csikós, G. - Juhász, T. (2016): Y and Z Generations at Workplaces. Journal of Competitiveness, 8 (3), p. 90-106. DOI: 10.7441/joc.2016.03.06.

Bencsik, A. - Machova, R. (2016): Knowledge Sharing Problems from the Viewpoint of Intergeneration Management. In: ICMLG2016 - 4th International Conference on Management, Leadership and Governance: ICMLG2016 (p. 42). Academic Conferences and publishing limited

Berke, Sz. - Kömüves, Zs. (2016): Satisfaction, motivation and personality types by sales leaders in SME sector: a pilot study. In: Andrea Csata (szerk.): Integration and modernization opportunities on the edge of Europe: Challenges in the Carpathian Basin: 13th Annual International Conference on Economics and Business. 1102 p. Kolozsvár: Editura Risoprint p. 1-16. (ISBN:978-973-53-1855-0)
Besenyei L. (2016): A generáció váltás forradalma. Opus et Educatio, 3 (4), p. 371-378.

Broennimann, A. (2017): Gen Z at work. Meet the next generation of hospitality professionals. Swiss Education Group (https://www.thegeneration-z.com/) p. 21.

Crampton, S. M., Hodge, J. W. (2007). Generations in the workplace: Understanding age diversity. The Business Review 9 p. 16-23.

Drenth, P. J. D. - Thierry, H. - De Wolff C. J. (1998): Handbook of Work and Organizational Psychology (2nd Edition). East Sussex, Psychology Press Ltd.

Elida-Tomita T. (2010): The evolution of conflict as a behavior process within global organizational communication management. Annales Universitatis Apulensis Series Oeconomica, 12 (2), p. 721-727.

Elmore, T. (2014). How Generation Z Differs from Generation Y. Retrieved July 01, 2015, http://growingleaders.com/ blog/generation-z-differs-generation-y/.

Ferincz A. - Szabó Zs. R. (2012): Z generáció hatása a munkáltató szervezetekre. Munkaügyi Szemle (2) p. 89-90.

Hale, W. G. -Margham, J. P. - Saunders, V. A. (1997): Biológia Értelmező Szótár. Budapest: Panem Kft.

Hochwarter, W. A. - Rogers, L. M. - Summers, J. K. - Meurs, J. A. - Perrewé, P. L. - Ferris, G. R. (2009): Personal control antidotes to the strain consequences of generational conflict as a stressor: A two-study constructive replication and extension. Career Development International, 14 (5), p. 465-486.

Howe, H. - Strauss, W. - Matson, R. J. (2000): Millenials rising: The next great generation. New York: Vintage

Ivancevich, J. - Matteson M, (2002): Organiational Behavior and Management. London: McGraw-Hill

Johnson, J. A. - Lopes, J. (2008): The intergenerational workforce revisited. Organizational Development Journal, 26 (3), p. 1-37.

Joshi, A. - Dencker, J. C. - Franz, G. - Martocchio, J. J. (2010): Unpacking the generational identities in organizations. Academy of Management Review, 35 (3), p. 392414.

Jurkiewicz, C. L. - Brown, R. G. (1998): GenXers vs boomers vs Matures: Generational compaisons of public employee motivation. Review of Public Personnel Administration, 18, p. 18-37.

Karp, H. - Fuller, C. - Sirias, D. (2001): Bridging the boomer gap: Creating authentic teams for high performance at work, Palo Alto: Daris Black Publishing

Kertzer, D. I. (1983): Generation as a sociological problem. Annual Review of Sociology, (9), p. 125-149.

Keszi-Szeremlei A. - Piricz N. (2015): A család és a gyerek érték: Családbarát munkahely cím elnyerésének pozitív hatásai a munkahelyre és az alkalmazottakra a Dunaújvárosi Főiskolán. In: András István - Rajcsányi-Molnár Mónika - Németh István Péter (szerk.): Szimbolikus közösségek. Dunaújváros: DUF Press, p. 245-256. (ISBN:978-963-9915-61-9)

Krajcsák Z. (2018): Az alkalmazotti elkötelezettség relatív fontossága a munka megváltozó világában. Vezetéstudomány/Budapest Management Review, 49 (2), p. 38-44. DOI: 10.14267/VEZTUD.2018.02.04. 
Kupperschmidt, B. R. (2000): Multigenerational employees: Strategies for effective management. The Health Care Manager, 19, p. 65-76.

Lancaster, L. C. - Stillman, D. (2002): When generations collide: Traditionalists, baby boomers, generation Xers, millennials: Who they are, why they clash, how to solve the generational puzzle at work, New York: Harper Collins

Lukovszki L. (2015): Generációk és vállalkozók. Marketing \& Menedzsment, (4), p. 55-57.

Makra E. - Farkas, D. - Orosz, G. (2012): A munka-család konfliktus kérdőív magyar validálása és a munka-család egyensúlyra ható tényezők. Magyar Pszichológiai Szemle, 67 (3), p. 491-518.

Mannheim, K. (1952): The sociological problem of generations: essays on the sociology of knowledge. London: RKP.

Mccrindle, M. - Wolfinger, E. (2010): Az XYZ ábécéje. A nemzedékek meghatározása. A nemzedékek meghatározása. Korunk, (3), p.13-19. ISSN: 1222-8338

Meretei B. (2017): Generációs különbségek a munkahelyen. Vezetéstudomány, 68 (10), p.10-18. DOI: 10.14267/VEZTUD.2017.10.02.

Messarra, L. C. - Karkoulian, S. - El-Kassar, A. N. (2016): Conflict resolution styles and personality The moderating effect of generation $\mathrm{X}$ and $\mathrm{Y}$ in a non-Western context. International Journal of Productivity and Performance Management, 65 (6), p. 792-810 DOI: 10.1108/ IJPPM-01-2016-0014

Molnár B. (2016): Új generációk a munkahelyeken: ezek a fiatalok! Heti Világ Gazdaság, (7), p. 50.

Molnár N. - Orosz G. (2017): A munkahelyi destruktív és konstruktív versengés kapcsolata a munka-család konfliktussal. Alkalmazott Pszichológia, 17 (2), p. 7-28. DOI: 10.17627/ALKPSZICH.2017.2.7.

Nádházy Zs. (2016): A konfliktusokról és feloldásuk lehetséges útjairól. Munkaügyi Szemle, (3), (ISSN 2064-3748)

Neil, S. (2010): Leveraging generational work styles to meet business objectives. Information Management Journal, 44, p. 28-33.

O'Bannon, G. (2001): Managing our future: The Generation X factors. Public Personell Management, 30, p. 95-109.

Olšovská, A. - Mura, L. - Švec, M. (2015): The most recent legislative changes and their impact on interest by enterprises in agency employment: what is next in human resource management? Problems and Perspectives in Management, 13 (3), p. 47-54.

Patterson, C. (2005): Generatinal diversity: Implications for consultation and teamwork. Paper Presented at the meeting of the Council of Directors of School Psychology Programs on generational differences. Deerfield Beach, FL

Pregnolato, M. - Bussin, M. H. R. - Schlechter, A. F. (2017): Total rewards that retain: A study of demographic preferences. SA Journal of Human Resource Management, 15 , p. $1-10$.

Sajtos L. - Mitev A. (2007): SPSS Kutatási és adatelemzési kézikönyv. Budapest: Alinea Kiadó, (ISBN: 978-9639659-08-7)
Shragay, D. - Tziner, A. (2011): The Generational Effect on the Relationship between Job Involvement, Work Satisfaction, and Organizational Citizenship Behavior. Colegio Oficial de Psicólogos de Madrid, 27 (2), p. 143157. ISSN: 1576-5962 http://dx.doi.org/10.5093/tr2011v$27 \mathrm{n} 2 \mathrm{a} 6$

Singh, A. (2014): Challenges and Issues of Generation Z. IOSR Journal of Business and Management (IOSRJBM), 16 (7), p. 59-63.

Slabbert, D. (2004): Conflict management styles in traditional organisations. The Social Science Journal, 41, p. 8392 DOI:10.1016/j.soscij.2003.10.007

Smola, K. W. - Sutton, C. D. (2002): Generational differences: Revisiting generational work values for the New Millenium. Journal of Organizational Behavior, 23, p. 363.

Soós J. K. (2008): Generációk találkozása: értékrendek ütközése, vagy hatékony együttmüködés? Munkaügyi Szemle, 52 (1), (ISSN 2064-3748)

Soulez, S. - Soulez, C. G. (2011): Recruitment marketing and generational segmentation: a critical analysis based on a sub-segment of generation Y. Recherche et Application en Marketing, 26 (1), p. 39-55.

Spaho, K. (2013): Organizational Communication and Conflict Management. Management, 18 (1), p. 103-118. DOI: http://hrcak.srce.hr/management?lang=en.

Stam, D. - Knippenberg, D. - Wisse, B. - Pieterse, A. (2016): Motivation in Words: Promotion - and Prevention - Oriented Leader Communication in Times of Crisis. Journal of Management, 44 (7), p. 859-887. https://doi. org/10.1177/0149206316654543

Svelta E. (2014): Munkaügyi konfliktusok és rendezésük. Nemzeti Közszolgálati Egyetem, http://vtki.uni-nke.hu/ uploads/media_items/munkaugyi-konfliktusok-es-rendezesuk.original.pdf Letöltés ideje: 2016.11.30. 11:09

Szabó A. - Kiss B. (2013): A generációs konfliktusok kutatásának fogalmi kiindulópontjai. Politikatudományi Szemle, 22 (4), p. 97-115.

Tari A. (2010): Y generáció - Klinikai pszichológiai jelenségek és társadalomlélektani összefüggések az információs korban. Budapest: Jaffa Kiadó

Tjosvold, D. - Johnson, W. - Johnson, R. T. - Sun, H. (2003): Can Interpersonal Competition Be Constructive Within Organizations? The Journal of Psychology, 137 (1), p. 6384.

Weil, $N$. (2008): Welcome to the generation wars: As boomer bosses relinquish the reins of leadership to generation $\mathrm{X}$ both are worrying about generation Y. CIO, 21.

Westerman, J. W. - Yamamura, J. H. (2007): Generational preferences for work environment fit: effects on employee outcomes, Career Development International, 12 (2), p.150-161. https://doi. org/10.1108/13620430710733631

Whitney, J. G. - Greenwood, R. A. - Murphy, E. F. (2009): Generational differences in the workplace: Personal values, behaviors, and popular beliefs. Journal of Diversity Management, 4, p. 1-8.

Zubány E. (2008): Éljünk a sokszínűséggel! Munkaügyi Szemle, 52 (1), p. 35-37. (ISSN 2064-3748). 